\title{
Foreign Experience -Creativity in the Personfactor of Development of Qualities
}

\author{
Utkir Tolipov', \\ ${ }^{1}$ Doctor of Pedagogical Sciences, Professor Tashkent State Pedagogical University named after Nizami \\ Tashkent, Uzbekistan
}

\begin{abstract}
.
Economically developed countries have extensive experience in developing creative personality traits. Founders of personal creativity - J.P.Gilford, E.P.Torrens, H.Gardner, T.M.Amabile,K.Robinson and others investigated the development of creativity of an individual. It is advisable to study foreign experience in developing creative personality traits as well as enriching this experience with new ideas. This process requires taking into account the social changes that have occurred over the past half century. This is the subject of study of this article.
\end{abstract}

Keywords: reativity, creative personality, development of personality creativity, foreign experience in developming personality creativity.

Article Received: 16th October, 2020; Article Revised: 30th December, 2020; Article Accepted: 08th January, 2021

\section{Introduction}

The problem of shaping the qualities of creativity in the individual has been consistently studied since the 1960s in economically leading countries. It was at this time that the creation of computer technology ushered in a new era in the history of human society, and the human mind became the basis for its recognition as an important factor in determining the future. The creation of computer technology has proved that a single idea can have a significant impact on all spheres of society, reduce the monitoring process, which takes months and years, and achieve labor efficiency and productivity by saving time. Therefore, in the economically hegemonic countries, the main attention was paid to the further optimization of human labor, which is carried out by manual or technical means through the creation of new ideas. The subjective phenomenon, which reflects the process of original thinking, which is assessed as "creativity", today has become a "base point" that determines the development in all spheres of society. This, in turn, has led to the urgency of the issue of educating a creative thinker.

\section{The main results and findings}

Gardner (Gorvard Gardner) explains the concept in his research: "Creativity is a practical action performed by a person, which must reflect a certain innovation and have a certain practical value". Tereza M. Amabile (Teresa M. Amabile; 1989) defines this concept as"the acquisition of high-level skills along with the thorough knowledge acquired in a particular field" $[7,6]$, and M.H. "creative" - "creative ability that characterizes the readiness of the individual to produce new ideas and is part of the talent as an independent factor'"[7, 67].

In the interpretation of T.I. Gritsay, P.I. Chernetsov, creativity is understood as the birth of unusual ideas, deviating from the traditional pattern of thinking, the creative ability to express quick solutions to problematic situations [6]. According to the approach of E.P. Torrens, creativity is a general intellect, an ability that is formed on the basis of the existing state of individual characterization and productive thinking. Inadequate creative knowledge is reflected in the process of adding to it a new structure and relevant information, filling in the missing information, searching for new solutions, analyzing them and publishing the results [4].

In our opinion, creativity is the ability to create many ideas of practical value, which saves 
time, energy, and creates a product that is easy to use in every way.

Any idea is a product of consciousness and thinking. There are several types of thinking. In particular: 1) according to the content: theoretical; practical (empirical), logical (analytical) and intuitive (intuitive) thinking; 2) by means: verbal-logical; exhibition-figurative and exhibition-action; 3 ) according to: effective (productive) and productive (reproductive; reworked) thinking; 4) according to what happens: voluntary and involuntary thinking; 5) real (based on oral and written speech, as well as action)and autistic (based on inner experience) thinking [2, 254].

In order to be able to advance creative ideas, a person must have developed creative thinking. This type of thinking differs from other forms of thinking in that it demonstrates the ability to "successfully participate in the development, evaluation, and refinement of ideas in a process aimed at acquiring innovative, effective decisions or new knowledge or expressing imagination" [9].

In a person, creative thinking does not develop spontaneously. The creative person's activity reflects the ability to consistently promote new ideas, make wise decisions in finding a solution to a problem, interpret the product in a unique way, enrich it with original elements and achieve a result (product) of practical value.

It should also be noted that Joy Paul Gilford has also made great strides in identifying the creativity that is manifested in the individual, his performance, and the structural foundations that make them up. In particular: the ability to see the problem and solve it easily; be able to categorize a wide range of concepts independently of associations; speed of thinking describing rich and diverse ideas; the flexibility of thinking that represents the ability to move from one problem to another, from one problem to another; originality (originality); non-standard thinking; the richness of the imagination; breadth of imagination; ability to be creatively inspired [5, 32].
In the field of psychology and pedagogy, a number of studies have been conducted in foreign countries to diagnose and assess the creative qualities of the individual.

The methodology, developed by American psychologist and educator Joy Paul Gilford, serves as a methodological basis for determining and assessing the level of development of creative qualities in high school students in general secondary schools, as well as in adults. This methodology is designed to determine and assess the level of creative thinking of a person and is based on a test.

It should be noted at this point that many acknowledge that creative thinking and creative thinking (i.e., creativity and ingenuity) represent exactly the same situation. In fact, both concepts - creative and creative thinking (creativity and creativity) represent two different states.

If creative thinking serves to create a creative product, creative thinking promotes new, original ideas, based on which the problem helps to find a solution to the problem. But both are the same criteria for the result (product) of creative and creative thinkingcan be identified, evaluated.

Joy Paul Gilford puts forward the idea that a person's level of creativity can be determined by three criteria:

1) speed (T); this factor implies the speed of creative thinking; the speed of creative thinking is determined by the number of total responses recorded by the subjects;

2) flexibility (E); this factor represents a rapid transition from one idea to another;

$3)$ originality $(\mathrm{O})$; this factor characterizes the specificity of creative thinking, an unconventional approach to a problem, creativity.

The author also puts forward a formula that serves to determine the level of a person's creative thinking. According to this formula, the speed of a person's creative thinking (IT) is calculated on the basis of the mutual sum of his speed (T), flexibility $(\mathrm{E})$, originality $(\mathrm{O})$. That is: $\mathrm{IT}=$ $\mathrm{T}+\mathrm{E}+\mathrm{O}[8]$. 
Joy Paul Gilford's ideas were further enriched later. In particular, TI Vinogradova believes that the following indicators are also important in determining the level of creative thinking of a person: speed (organization of many effective practical actions by a person to solve tasks positively or find answers to problematic issues); flexibility (directed to the productive functioning of thinking that serves to understand the difference between objects, processes, or components of a system; usually a person with thinking that serves to understand the difference seeks to perform the same actions or find solutions to the same problems); originality (in the development of ideas, efforts are made to identify their new ones (unexpected or statistically less observable) and to solve problems); sharpness of mind (intelligence; means sensitivity to abnormal details, contradictions, and uncertainties); possession of a metaphor (figurative meaning) (means the ability to perform completely unusual tasks or solve supernatural problems, to have a symbolic, association-based thinking, to see complexity in simple cases, and simplicity in complex situations); satisfaction [3, 2324].

In our opinion, these criteria are also able to determine and assess the level of individual creativity.In the course of the research, TI Vinogradova (Gritsay) tried to fill in the content of the added criteria, as well as to theoretically reveal the essence of the criterion of "satisfaction" (zero, in the work of TI Vinogradova (Gritsay) the essence of this criterion is not explained) we did.

1. Sharpness of mind - a quick grasp of the essence of the task, A goal is a quick grasp of a task given to a person with such a qualitywill be able to quickly understand the conditions, to put forward dozens of new ideas in a short time, to complete the task in a short time.

2. Possession of a metaphor (figurative meaning) - the use of words and phrases in figurative senses (for example, the eye the eye of the spring, the mouth - the mouth of the cave). In promoting creative ideas, a person effectively uses sarcastic phrases, figurative words and phrases.

3. Satisfaction - a positive state that means that the event, incident or process meets the needs, requirements, interests of the person, satisfies him, works with pleasure in the substantiation of creative ideas, ensures the achievement of satisfactory results.

For nearly a century, researchers have been conducting practical research to develop models of creative thinking. So far, G. Wallace, K. Rossman, A. Osborn, D. Perkins, S. Isaacsen, D. Treffinger have developed models of creative thinking.

Silvano Arieti's 1965 book, Creativity: A Miraculous Synthesis, analyzes the classical models of personality creative thinking proposed by researchers from 1908 to 1964, and their essence. The analysis reveals the following (Table 1):

Table 1.

Classical models of creative thinking

\begin{tabular}{|l|l|l|}
\hline № & Author & The essence of the model \\
\hline 1. & Graham & 1. Preparatory stage (characterized by problem statement, information \\
\hline
\end{tabular}




\begin{tabular}{|c|c|c|}
\hline & $\begin{array}{l}\text { Wallas, } \\
1926 \text { y. }\end{array}$ & $\begin{array}{l}\text { retrieval, study of popular ways). } \\
\text { 2. The incubation (creation) stage (represents the maturation of the idea, } \\
\text { if the popular ways do not help to solve the problem, then the task is } \\
\text { completed (problem solving)). } \\
\text { 3. The stage of clarification of thought (a favorable situation arises for } \\
\text { the creation of a new idea). } \\
\text { 4. The stage of determining the reliability of the idea (the solution is } \\
\text { analyzed in detail, its practicality and suitability are determined) }\end{array}$ \\
\hline 2. & $\begin{array}{l}\text { BettyB. } \\
\text { Rossman } \\
1931 \text { y. }\end{array}$ & $\begin{array}{l}\text { 1. Identify a need or problem. } \\
\text { 2. Need or problem analysis. } \\
\text { 3. Study the problem on the basis of data generalization. } \\
\text { 4. Formulate all solution options. } \\
\text { 5. Analyze solution options in terms of their advantages and } \\
\text { disadvantages. } \\
\text { 6. Invention is the birth of new ideas. } \\
\text { 7. Organize an experiment in order to find the most effective solution, } \\
\text { select the optimal solution and process it and bring it to an end }\end{array}$ \\
\hline 3. & $\begin{array}{l}\text { Alex } \\
\text { Osbourne } \\
1953 \text { y. }\end{array}$ & $\begin{array}{l}\text { 1. Referral (problem identification). } \\
\text { 2. Preparation (collection of information related to the problem). } \\
\text { 3. Analysis (analysis of information). } \\
\text { 4. Gather alternative ideas. } \\
\text { 5. Incubation (coverage of evidence). } \\
\text { 6. Synthesis (generalization of individual ideas). } \\
\text { 7. Evaluation (evaluation of ideas) }\end{array}$ \\
\hline
\end{tabular}

E.P. Torrens noted in his time (1988) that Graham Wallace's model served as the basis for many programs that taught the individual to think creatively, which is still relevant today. [13]

Getting acquainted with the classic models of creative thinking allows you to clearly see the differences between creativity and creativity. In our opinion, the difference between them is as follows (Table 2): 
Table 2.

Differences between creativity and creativity

\begin{tabular}{|c|c|c|c|c|c|}
\hline № & Attributes & Purpose & Process & The result & Practical value \\
\hline 1. & Creativity & $\begin{array}{l}\text { Creating a } \\
\text { creative } \\
\text { product (work, } \\
\text { product) with } \\
\text { artistic and } \\
\text { aesthetic value }\end{array}$ & $\begin{array}{l}\text { 1. Emotional } \\
\text { exposure. } \\
\text { 2. The emergence } \\
\text { of the idea. } \\
\text { 3. Justify the } \\
\text { idea. } \\
\text { 4. Creating a } \\
\text { product (work, } \\
\text { product) based on } \\
\text { the idea }\end{array}$ & $\begin{array}{l}\text { To have a } \\
\text { creative } \\
\text { product (work, } \\
\text { product) with } \\
\text { artistic and } \\
\text { aesthetic value }\end{array}$ & $\begin{array}{l}\text { To give artistic } \\
\text { and aesthetic } \\
\text { pleasure to the } \\
\text { person, } \\
\text { satisfy artistic } \\
\text { and aesthetic } \\
\text { taste }\end{array}$ \\
\hline 2. & Creativity & $\begin{array}{l}\text { Promoting } \\
\text { original ideas } \\
\text { that allow you } \\
\text { to create }\end{array}$ & $\begin{array}{l}\text { 1. Understand the } \\
\text { problem. } \\
\text { 2. Analyze the } \\
\text { data to find a } \\
\text { solution to the } \\
\text { problem based on } \\
\text { the principle of } \\
\text { cause and effect. } \\
\text { 3. Advance many } \\
\text { ideas (options) on } \\
\text { the solution of the } \\
\text { problem. } \\
\text { 4. Identify the } \\
\text { most effective } \\
\text { solution } \\
\text { analyzing the } \\
\text { existing ideas } \\
\text { (options). } \\
\text { 5. State the } \\
\text { solution }\end{array}$ & $\begin{array}{l}\text { Having ideas } \\
\text { of a creative } \\
\text { nature (adding, } \\
\text { re-creating, } \\
\text { modifying, } \\
\text { substantiating, } \\
\text { creating) }\end{array}$ & $\begin{array}{l}\text { Creating in the } \\
\text { person, creating } \\
\text { an incentive to } \\
\text { create, } \\
\text { developing } \\
\text { creativity }\end{array}$ \\
\hline
\end{tabular}

Over the last forty years, the classical models of creative thinking have been improved in content, enriched with modern models (Table 3):

Table 3.

Modern models of creative thinking

\begin{tabular}{|l|l|l|}
\hline № & Authors & The essence of the model \\
\hline & & $\begin{array}{l}\text { 1. Arrange existing needs to avoid confusion. } \\
\text { 2. Mental mobility. } \\
\text { 3. The ability to find a problem that sets it apart from others. }\end{array}$ \\
1. & $\begin{array}{l}\text { Dwight H.Perkins } \\
1981 \mathrm{y} .\end{array}$ & $\begin{array}{l}\text { 4. Lack of risk, lack of desire to fail. } \\
\text { 5. Ability to hear serious criticism of the case and seek the help of } \\
\text { experienced colleagues without feeling embarrassed. } \\
\text { 6. Internal motivation based on strong beliefs and confidence in } \\
\text { one’s own views }\end{array}$ \\
\hline
\end{tabular}




\begin{tabular}{|c|c|c|}
\hline 2. & $\begin{array}{l}\text { Don Koberg, } \\
\text { Jim Bagnall } \\
1981 \mathrm{y} .\end{array}$ & $\begin{array}{l}\text { 1. Accept the situation (like an invitation). } \\
\text { 2. Analysis (to open the "world of problems"). } \\
\text { 3. Identification (key questions and purpose). } \\
\text { 4. Idea (to create options). } \\
\text { 5. Selection (to choose from among the options). } \\
\text { 6. Putting it into practice (to turn an idea into action). } \\
\text { 7. Evaluation (revision and rescheduling) }\end{array}$ \\
\hline 3. & $\begin{array}{ll}\text { James } & \text { F. } \\
\text { Bandrowski } & \\
1985 \mathrm{y} . & \end{array}$ & $\begin{array}{l}\text { 1. Analysis. } \\
\text { 2. Standard planning. } \\
\text { 3. Understanding development. } \\
\text { 4. Creative approach. } \\
\text { 5. Creative race. } \\
\text { 6. Strategic relations. } \\
\text { 7. Solution. } \\
\text { 8. Creating a concept. } \\
\text { 9. Critical discussion. } \\
\text { 10. Planning. } \\
\text { 11. Action planning. } \\
\text { 12. Creative planning for contingencies. } \\
\text { 13. Movement. } \\
\text { 14. Introduce the idea on the basis of adaptation. } \\
\text { 15. Monitoring results }\end{array}$ \\
\hline 4. & $\begin{array}{l}\text { Scott G. Isaksen } \\
\text { Donald J. Treffinger } \\
1985 \text { y. }\end{array}$ & $\begin{array}{l}\text { 1. Goal (goal setting). } \\
\text { 2. Evidence (identification of evidence). } \\
\text { 3. Problem (problem setting). } \\
\text { 4. The idea (to put forward several options for a solution). } \\
\text { 5. Solution (determine the optimal solution from several options). } \\
\text { 6. Express the solution }\end{array}$ \\
\hline 5. & $\begin{array}{l}\text { Robert Fritz } \\
1991 \text { y. }\end{array}$ & $\begin{array}{l}\text { 1. Having a target (first spark). } \\
\text { 2. Prediction. } \\
\text { 3. Existing reality. } \\
\text { 4. Take action. } \\
\text { 5. Correction, study, evaluation, correction. } \\
\text { 6. Reason to create. } \\
\text { 7. Completion. } \\
\text { 8. Use your own creative product } \\
\end{array}$ \\
\hline 6. & $\begin{array}{l}\text { Sidney J.Parnes } \\
1992 \text { y. }\end{array}$ & $\begin{array}{l}\text { 1. Objective finding. } \\
\text { 2. Identify the evidence. } \\
\text { 3. Search for the problem. } \\
\text { 4. Search for a solution. } \\
\text { 5. Acceptance of the invention }\end{array}$ \\
\hline
\end{tabular}

Based on acquaintance with modern models of creative thinking, it can be concluded that the level of creative thinking is the speed of thought,a comprehensive analysis of the situation, advancing many ideas as a solution, synthesizing them, choosing the most optimal option as a solution, describing the solution, the effectiveness of intellectual and kinesthetic action aimed at creating a product with practical value based on the solution.

American psychologist, educator E.P. Torrens has a special role in the formation and development of creativity in the 
individual. E.P. Torrens asked himself, "How can creativity be effectively shaped in the individual?" asked the question and tried to find a practical solution for it. $\mathrm{He}$ offered a set of tests as a practical solution. The purpose of the E.P. Torrens tests is to determine a person's attitude toward problem situations, their passion for solving problem situations, and their creative qualities. The difference between this test and most tests is the respondent problem $[10 ; 11]$.

The set of tests proposed by E.P. Torrens allows to determine whether a person has the ability to think, the ability to express ideas in an original way by performing

\section{Complete the pictures}

(the respondent should complete them on the basis of 10 unfinished base figures, create a new image and name it). The respondent should describe what he imagines when he sees the barcode. For pictorial tasks. The respondent completes a pictorial task in three variants. Terms of the assignment: suggest as many ideas as possible; ignoring the artistic value of the paintings; not to set limits on one's thinking.

Assignments include:

1. Draw a picture (the respondent is offered a colored ovoid shape with a shape and size equal to a normal egg; the color of the shape is chosen arbitrarily; the color of the shape can be suggested by the respondent). For example, the respondent creates different names based on this shape in blue and names them:

example, when the first barcode is completed, it could be an open book, two glasses standing side by side, a double ball. The following barcodes are presented to the respondent:
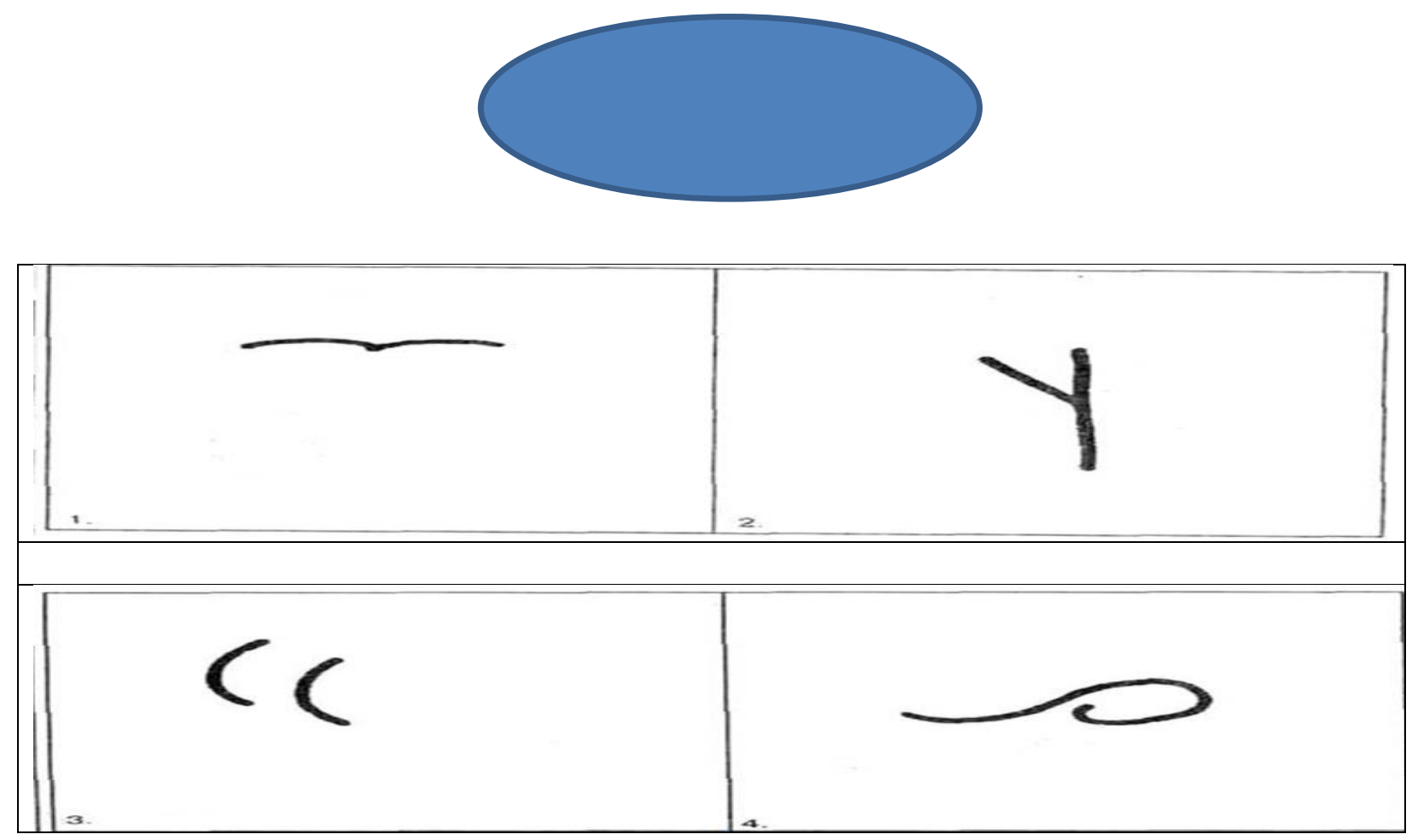


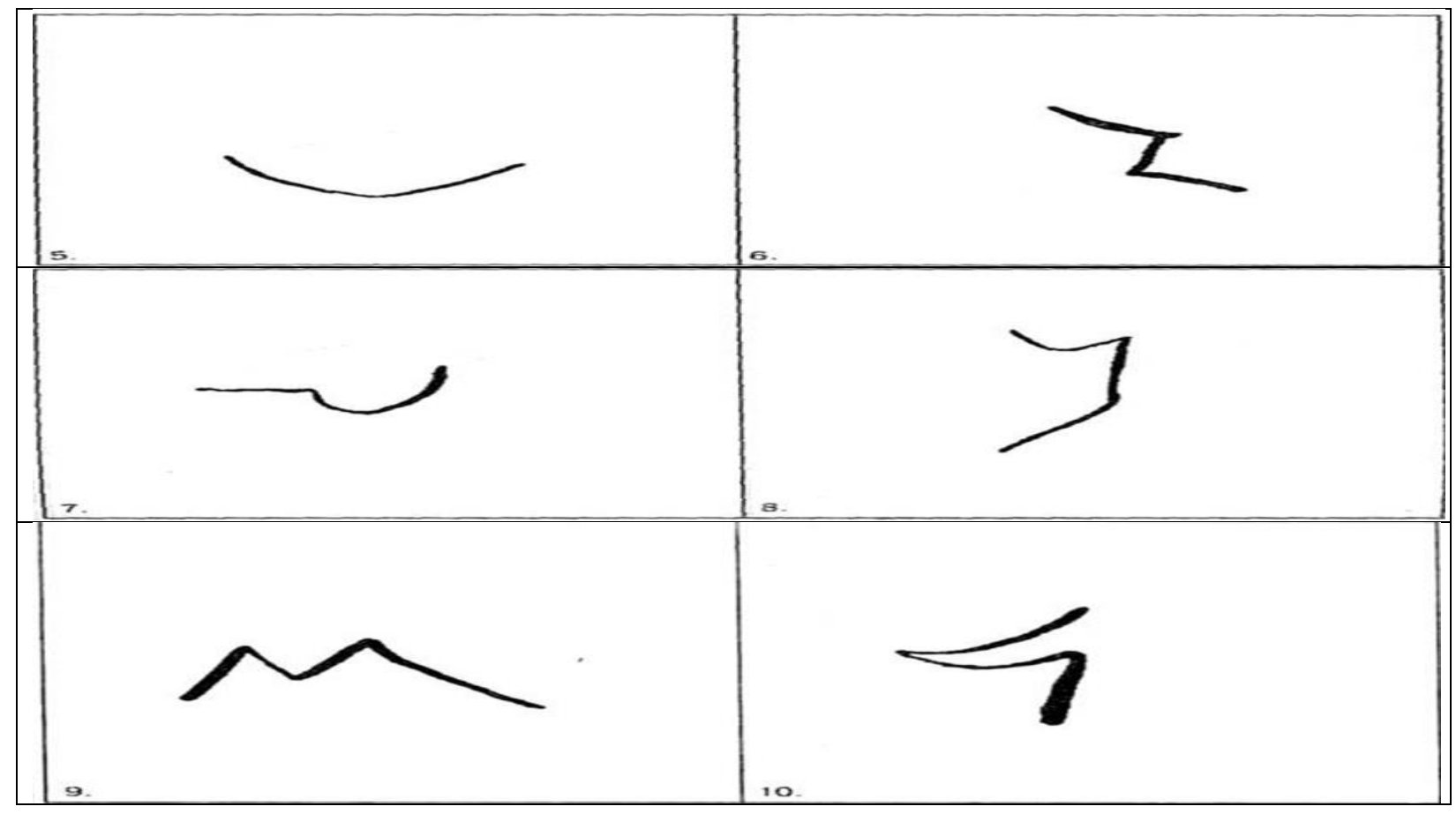

\section{Repetitive lines.}

The base material is 30 pairs of parallel vertical lines. On the basis of each pair of lines it is necessary to draw some kind of repeating pictures.

As with any test, the results of E.P. Torrens' Incomplete Drawings test are calculated using certain criteria and corresponding indicators.

Currently, the PISA test assesses students' literacy, level of knowledge, ability to apply theoretical knowledge in practice in four areas: reading literacy, mathematical literacy, science literacy and computer literacy. From 2021, creativity will be included in the criteria of the PISA (Program for International Student Assessment) test [12]. The ideas for the PISA test were based in 1997 and were first applied in educational practice in 2000. Held every three years in different countries of the world, this test serves to assess the level of educational achievements of students. According to it, students' literacy, level of knowledge and ability to apply existing theoretical knowledge in practice are assessed. 15year-old students are involved in the testing process. The PISA, which operates as a consortium, is led by the Australian
Board of Education Research (ACER). In essence, the consortium (consortium partnership, joint participation; PISA - an agreement to jointly implement an educational investment project) in the activities of the Dutch National Institute of Pedagogical Occupation (CITO), the U.S. Educational Testing Services - ETS), Japan National Institute for Educational Research (NIER), Vestat (WESTAT).

Uzbekistan's first participation in the international PISA survey is scheduled for 2021. According to the Resolution of the Cabinet of Ministers of the Republic of Uzbekistan dated December 8, 2018, the National Center for International Research on Education Quality Assessment was established [1]. The Center is constantly studying the creation of the necessary conditions for educational institutions to show positive results in international research.

The study of foreign experience in the development of creativity in the individual led to the following conclusions:

1. The problem of developing creativity, personality creativity and personality creativity in economically leading foreign countries attracted the attention of researchers a century ago. 
2. Although there are some differences in the theoretical descriptions of the concept of "creativity" by researchers, they all differ in their views on creativity, the promotion of many ideas as a solution to a problem, their comprehensive analysis, the search for an original solution. intersect.

3. According to our firm, creativity is the ability to create many ideas with practical value, which allows you to save time, energy, create a product that is easy to use in every way.

4. Classical and modern models of creative thinking have been developed by researchers in economically leading foreign countries. In developing models of creative thinking, researchers have taken into account the stages of mental operations in the process of thinking, thinking.

5. Wallace Grem, Betty B. Rossman, Alex Osborn, Dwight X. Perkins, Don Koberg, James F. Bandrovskiy, Scott G. Isaksen, Robert Frits, Sidney Dj. Models of creative thinking based on researchers such as Parns still have practical value today, based on which there is an opportunity to develop creative thinking in the individual.

6. In our opinion, the level of creative thinking is intellectual and kinesthetic aimed at intellectual speed, comprehensive analysis of the situation, advancing many ideas as a solution, synthesizing them, choosing the most optimal option as a solution, describing the solution, creating a product with practical value determined by the effectiveness of the action.

7. In the context of global information, the problem of developing creative qualities in the individual is relevant. Therefore, starting from 2021, the PISA program, which assesses the general level of knowledge of students, plans to include criteria for assessing creative literacy as the fifth of the four main areas (reading literacy, mathematical literacy, science and computer literacy).

\section{Conclusion}

Thus, in the context of global information, the development of creative qualities in a person by directing his inner potential to useful work is put on the agenda as a topical pedagogical issue. To solve this task effectively, it is necessary to have a sufficient understanding of the essence of concepts such as creativity, creative qualities and the development of creative qualities. On the basis of creativity, the course of the thought process is taken into account. For this reason, a group of researchers has conducted research over the past hundred years to create models of creative thinking. The creative thinking models based on them are still of practical value today. These models serve to ensure the effective passage of the process of developing the qualities of keratinism in the individual.

\section{References:}

[1] Resolution of the Cabinet of Ministers of the Republic of Uzbekistan "On measures to organize international research in the field of assessing the quality of education in public education" // http://lex.uz/docs/ 4097073.

[2] Vinogradova (Gritsay) T.I. From the history of the study of creativity in domestic and foreign psychology // Pedagogy and psychology: trends, problems, urgent tasks. Mat. V International scientific and practical conference.

- Krasnodar: 2014 .-- P. 23-24.

[3] Vinogradova E.V. Creative learning models // https://pglu.ru/ upload / iblock / bb8 / uch_2010_i_00013.pdf.

[4] Guilford J. Structural model of intelligence. Psychology of thinking. - M .: Progress, 2003 .-$75 \mathrm{p}$.

[5] Gritsay T.I., Chernetsov P.I. Research of the creativity of high school students // https://cyberleninka.ru/article/n/issl 
edovanie-kreativnosti-

starsheklassnikov.

[6] Creative pedagogy / Textbook.

M.H.Usmonbaeva et al. - Tashkent:

"Navruz" publishing house, 2019. -

6-7-p.

[7] Mamontova T.S. To the question of the conditions for the development of creativity in senior classes of secondary schools // J. Scientific Dialogue. - M .: 2018. - No. 1. Pp. 231-243.

[8] The main approaches to the assessment of the creative thinking of primary school students // http://skiv.instrao.ru/support/demo nstratsionnye-materialya/ KM 2019 basic $\%$ 20approaches.pdf.

[9] Torrance's creativity test. Diagnostics of creative thinking //https://psycabi.net/testy/577-testkreativnosti-torrensa-diagnostikatvorcheskogo- myshleniya.

[10] Torrance's creativity test // http://www.miu.by/kaf_new/mpp/ 150.pdf.

[11] What is PISA?http://virtuallab.by/publ/pisa/ pisa/chto takoe pisa/47-1-0-317.

[12] Working Paper: Models for the Creative Process by Paul E. Plsek //http://www.directedcreativity.com /pages/WPModels.html.

[13] Tolipov U.K. The question of improving the process of retraining and advanced training of pedagogical personnel is the dictates of the time. Hrvatski znanstveni glasnik,№ 3, 2020

[14] Utkir Tolipov, Khamidjan Matyakubov. Methodology for the Formation of Research Competencies inJunior Students of a Pedagogical U. International Journal of ProgressiveSciences and Technologies (IJPSAT) 